count; passed restless nights; became excited; said he was the second Saviour of the world. Threw away his money; said it was not right for him, a divine person, to hoard up wealth.

T. B-_; a labourer; sober and steady. Has been latterly in the habit of reading the Bible and religious books; sitting up late at night, depriving himself of rest and proper sustenance. Said he could influence the course of the sun and the motions of the heavenly bodies.

E. W-. Suffered from ill health, and fretted in consequence. Said the Lord had been with him all night and converted him, and had performed a miracle upon him by enabling him to see without spectacles, which he had worn from his youth; that he had amassed a fortune, and should become a minister of the Gospel.

T. K. G- S- Said he was dead. Rolled himself up in sheets as if in a shroud, and desired an undertaker should be sent for to measture him for a coffin; said it must be a large one, as he had grown to a great size.

H. B . Became violent. Talked incoherently. Said he was the son of Garibaldi-the Son of God; that he had been crucified, and was the Saviour of the world; that he could see from London to Haslar Hospital at Portsmouth.

E. E-. Became insane from domestic grief caused by the misconduct of a sister to whom he was much attached. Said he was in hell; that there was a large clock there; that it had seven hands, fire of them being his children, and the other two his sister's bastards; that they were all pointing at him, and would soon get him into their clutches and tear him to pieces.

T. E- Said his wife and children were in hell; that his house and effects must be burned, as a penalty upon him for not having told the truth to Jesus Christ in a conversation he had with him.

J. C-. Passed several sleepless nights. Was restless and uneasy for many days. Said he saw imps flitting in the air.

G. N-. Being much depressed, he began to have delusions. Said that the sheet of his bed was his shirt; that the quilt was his trowsers; that he caught birds in his bed -a goldfinch, a canary, and a lark. Took up pieces of rags, saying they were pigeons and crows. Folded up the carpet of his room, saying it was a railway.

R. T-. Said he was followed from place to place by police and soldiers; that men were in the house with hand cuffs to arrest him; that the house was filled with rats; that he saw the devil. Attempted suicide.

J. B- Was in St. George's Hospital for a severe attack of rheumatic fever. Said the nurse of the ward was attempting to poison him; that a coffin was ordered for him ; that a patient in the next bed was abetting the plot; that poisonous fluid was injected into him.

J. G-. Was in St. Mary's Hospital for an affection of the heart. Fancied that he should be burned in the hospital; that one of the patients in the same ward was constantly watching him and taking down his words; that other's were peering at and listening to him. Slunk into corners, and only spoke in whispers.

C. W- Entertained exalted ideas of himself and his circumstances. Said he was rich; that he was about to build a fine house; that he should keep a carriage and spirited horses; contract a splendid marriage; that he was raised to the peerage with the title of the Duke of Leeds; that he had direct personal communications with the Almighty.

P. B-. Became epileptic on the failure of some mining speculations. During the occurrence of the fits he fancies he is a stag. Tueaps about the room, \&c.

J. L-W Was unsuccessful in business. Fretted at this for several weeks; then began to have delusions. Said he saw a cofin in his room; in consequence of which he refused to go to bed; said there were ghosts in the house, and a strong smell of human blood.

J. H-. Suffered from headache, giddiness, failure of memory. Said there was a little man in his head, and that he must cut him out by taking off part of the skull.

$\mathrm{O} . \mathrm{H}^{\circ} \mathrm{C}-$. Said he dared not shake hands with anyone; that he was a divine being, just come down from heaven; that he should not remain long upon earth, but must go down to hell to see how things were going on there.

J. T. Spoke in a religious strain. Said he was commissioned by the Almighty to preach the gospel; that
God had appeared to him, and told him that he should convert the world, and should not die before mankind were brought into the fold of Christ.

C.S- Became affected in mind in consequence of seeing the body of a man suspended to a beam in a house which he was employed to force open. Said that Jesus Christ was coming to whitewash the house, and it must be got ready for him; that the Almighty had given him power to destroy the devil; that Hampton-cont Palace belonged to him; and that he bad a large sum of money in the bank.

W. G. M- Came downstairs without his clothing, and said the Almighty had told him to do so. A week after he rushed into the Serpentine with his clothes on and a carpet bag in his hand. Said he saw strangers in the house, and among them a man with a peculiar cap, who was the devil; that he heard voices desiring him to do such and such things; that he was a prophet.

Such are the fantasies of imagination, - the grotesque distortions, the broken lights, reflected by an unbalanced mind.

Hanwell, Nov. 1870.

\section{COLLOID TUMOUR OF THE ARM.}

BY CHARLES WILLIAMS, F.R.C.S., ASSISTANT-SURGEON, NORFOLK AND NORWICH HOSPITAL.

THE tumour in this case was removed from the arm of a man who was in the first instance admitted into the Norwich Hospital under the care of Mr. Nichols, in the year 1860 . At that time he was a strong, healthy farm-labourer, aged fifty-seven; and stated that about twelve months previously he noticed a hard swelling, somewhat larger than a horsebean, in the left arm. The growth slowly increased in size, and on admission there was seen to exist, at the inner and upper side of the biceps, a prominent tumour, very morable, and simply lying beneath the skin in the cellular tissue. This growth consisted of three distinct tumours. One was on the outer and upper side, the size of a large walnut, flattened in shape, having a smooth surface, though its margin was nodulated; it was of stony hardness, and apparently unconnected with the others. The second, placed on the inner side of the above, was oval in form, very soft, distinctly lobulated, and had a few hard nodules on it; it had the feel of a fatty tumour, and was not smaller than a hen's egg. The third was perfectly hard and movable, and not much larger than a horse-bean.

In December, 1860, these growths were removed. No. 1 was found to be extremely dense, so much so as almost to resist the edge of the knife; it contained no juice, and no cartilage could be detected anywhere about it. Under the microscope, portions of this substance exhibited the fibromembranous stroma of colloid, having very delicate, curved, and intersecting fibres, interspersed among which were granules of various sizes, and numerous oil-globules. No. 2 tumour was enveloped in a capsule, and composed of ambercoloured material, having the consistence of jelly. The microscope proved it to be comprised of distinct, well-marked loculi, delicate fibres, and a few cells. No. 3 tumour was of the same consistence and appearance as the first. Surrounding these tumours was a substance of a reddish colour, having the semblance of gelatine; this was found to contain the characteristic long, wavy fibres of colloid disease, unaffected by acetic acid.

My friend, Dr. Mackenzie Bacon, of Fulbourn, kindly sent a portion of these growths to Dr. Wilks, whose examination resulted in the opinion that they were a variety of fibrous or fibro-plastic tumour, sometimes recurrent. "Its likeness to colloid gave rise to the name collonema and gelatinous sarcoma by the older surgeons. The structure is very beautiful. I have lately had under my care a case of this kind, in which the tumour sprang from the pons Varolii of a child. The hard portion, though apparently different, is in composition rmuch the same, but the fibres are simpler and more compact. It is desirable to watch for recurrence in such cases."

With regard to the patient, the wound healed slowly, 
and, when nearly well, there appeared at its lower part a small growth, of the size of a nut. This was removed, and, on examination, was seen to be a cyst containing glairy fluid, which exhibited the usual reticulated character of colloid. After this the wound healed soundly, and the patient was dismissed in January, 1861.

In March of the present year the man applied a second time for admission into the hospital. The disease had recurred in his left arm, and had assumed very formidable dimensions; it occupied the whole of the anterior and internal aspects of the limb, and measured twelve inches and a half in length, and about twenty inches in circumference. In front of this growth was a smaller one, the size of an orange, hard and nodular, and was the first to make its appearance. Both were freely movable under the skin, to which they were unadherent, except at a spot of nlceration which had been produced by the friction of his clothes against the tumour. There was no enlargement of the

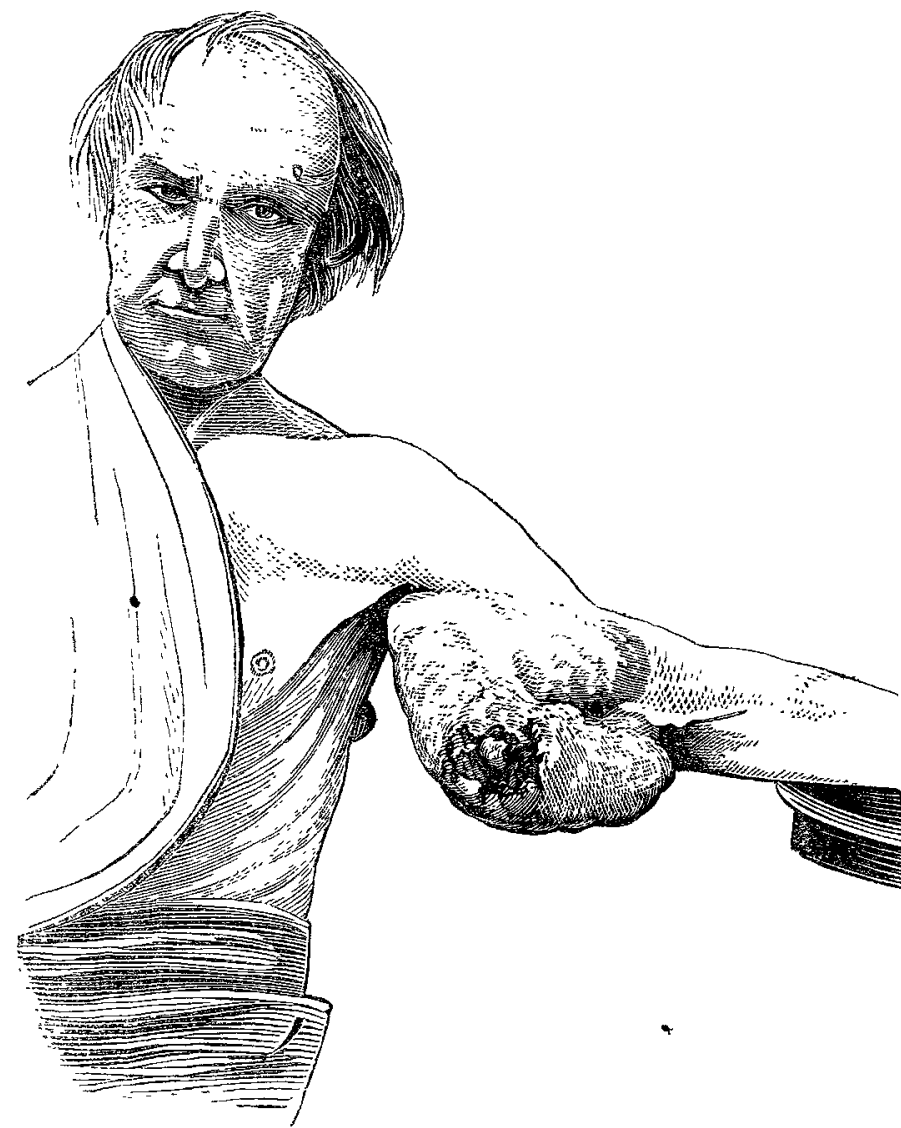

axillary glands. He was in possession of excellent health, and had been so for many years. No member of his family had ever suffered from cancer.

He stated that after leaving the hospital in 1861 he remained free from any recurrence until 1866; he then noticed a small tumour at the lower part of the cicatrix. Nine months before admission another tumour appeared, somewhat higher in the arm; this grew very rapidly, and in that space of time had attained the size indicated above. On the 18th of March INr. Nichols dissected out the mass, which was found to be lying immediately beneath the skin, having no attachment except to the superficial fascia. The hæmorrhage, chiefly venous, was very free.

When cut into, the tumour had a yellowish colour and translucent gelatinous appearance. The microscope revealed fibres so delicate as to require a very good defining power to discern them. They interlaced in all directions, but sprang in the first place from distinct centres. Oval nuclei were aggregated in clusters amongst the fibremeshes.

This case, I reoret to say, terminated unfavourably thirteen days after the operation. The patient never for one hour rallied after its removal. No suppuration took place. The pulse remained at 100; tongue dry, and a hot skin. Neither rigors nor diarrhca supervened.

At the post-mortem examination a large quantity of recent lymph and pus were found on the intestines. The pelvis contained a good deal of purulent serum. The omentum and all other organs within the thorax and abdomen were healthy, except the liver, which had a larga clot of extravasated blood in its right lobe.

I have not, in accordance with general custom, described this specimen in the title of the paper as "colloid cancer," simply because I believe it to be very doubtful indeed whether there is any connexion at all between true colloid and cancer. So far as I can judge from the few cases that have fallen under my notice in hospital and private practice, and also from those recorded in medical books and journals, I am induced to believe that colloid is a disease quite sui generis, and is neither carcinomatous in its character, nor frequently associated with cancer; and when seen in combination with the latter, such occurrence may be explained by the supposition that in all probability colloid disease has appeared in a person havins an hereditary tendency to cancer; and it has called into action the growth of this malignant disease much in the same way as the removal of an innocent tumour may be followed some time after by the growth of a cancer not far distant from the cicatrix. In this case the local injury caused by the removal of the nonmalignant tumour called into play what was required for the production of a cancerous growth. Is it not a fact that " in persons the subject of cancer, at some period, sooner or later, the thoracic or abdominal viscera, or some organs distant from the seat of the primary development, become invaded with the same disease? On the contrary, in colloid disease, the primary growth being removed, another may reappear over and over again; yet the development is confined in most cases to the immediate site of its first appearance, or to some part of the member to which it grew."**

"Another characteristic of these fibro-plastic growths, and a very marked one, is this-that in all stages of their growth, whether before or after ulceration of the integuments, the lymphatic system is not involved in the disease. In not one case shall we find that the lymphatic glands of an organ in which these tumours were growing had ever become infiltrated on the seat of a similar disease."

We are therefore justified in giving a favourable prognosis in these cases-much more so than if they were the subjects of cancer; and we are also justified in removing growths of this nature wherever they appear, inasmuch as, if the disease be not radically cured, it is slow in its recurrence.

I might refer to notes of other cases of colloid which have fallen under my observation, but must content myself with briefly recording one; that of a lady in this city, from whose right breast Mr. Nichols removed a small hard tumour. It was the size of a walnut, and contained material of the consistence of liquid glue, having the characteristic appearances of colloid when examined under the microscope. Exactly two years later, I again assisted in the removal of a smal elastic growth lying close to the arillary end of the cicatrix. The tumour proved to be a cyst containing colloid fluid. Five years later the disease had recurred in the form of a considerable tumour under the cicatrix. On examination after removal, it was found to consist of a large single cyst, having a thick, smooth, shining wall, and containing thin gelatinous matter. The lady is still living, and, I believe, in good health. It is now nine years since the first appearance of her disease.

We must admit that there existed, in these two cases, no feature common to the natural history of a cancer. Had such been the case, in neither would so long a lease of life been granted.

Colloid disease is by no means common. It is, indeed, of somewhat rare occurrence. Cancer, on the contrary, is very common. The statistics of any hospital would prove this At the Norfolk and Norwich Hospital I noticed in two years only 6 cases of the former to 148 of the latter.

Norwich, Nov. 1870

* Birkett, Guy's Hospital Reports, vol. iv.

Cholera in Southery Russia.-Cholera having ceased at all the Russian ports of the Black Sea and Azof, the Constantinople Board of Health has suppressed the quarantine on arrivals from those ports with the exception of Poti. A medical inspection will, however, be required before admitting ressels coming from them to free pratique. The arrivals from Poti are excepted, in consequence of the frequent communication between it and the interior of the country, where cholera still prevails.-Malta Times. 